\title{
Improved Sequencing of Oxidized Cysteine and Methionine Containing Peptides Using Electron Transfer Dissociation
}

\author{
R. Srikanth, ${ }^{\text {J Jonathan Wilson, }}{ }^{\mathrm{b}}$ Juma D. Bridgewater, ${ }^{\mathrm{a}, *}$

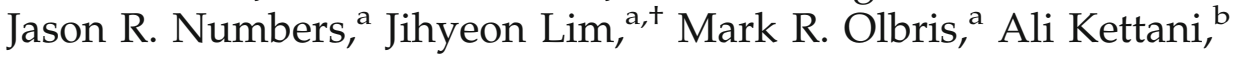 \\ and Richard W. Vachet ${ }^{a}$ \\ ${ }^{a}$ Department of Chemistry, University of Massachusetts, Amherst, Massachusetts, USA \\ ${ }^{\mathrm{b}}$ Bruker Daltonics, Inc., Billerica, Massachusetts, USA
}

Oxidative modifications to the side chains of sulfur-containing amino acids often limit the number of product ions formed during collision-induced dissociation (CID) and thus make it difficult to obtain sequence information for oxidized peptides. In this work, we demonstrate that electron-transfer dissociation (ETD) can be used to improve the sequence information obtained from peptides with oxidized cysteine and methionine residues. In contrast to CID, ETD is found to be much less sensitive to the side-chain chemistry, enabling extensive sequence information to be obtained in cases where CID fails to provide this information. These results indicate that ETD is a valuable technique for studying oxidatively modified peptides and proteins. In addition, we report a unique and very abundant product ion that is formed in the CID spectra of peptides having N-terminal cysteine sulfinic acid residues. The mechanism for this unique dissociation pathway involves a six-membered cyclic intermediate and leads to the facile loss of $\mathrm{NH}_{3}$ and $\mathrm{SO}_{2}$, which corresponds to a mass loss of $81 \mathrm{Da}$. While the facile nature of this dissociation pathway limits the sequence information present in CID spectra of peptides with $\mathrm{N}$-terminal cysteine sulfinic acid residues, extensive sequence information for these peptides can be obtained with ETD. (J Am Soc Mass Spectrom 2007, 18, 1499-1506) (c) 2007 American Society for Mass Spectrometry

$\mathrm{M}$ ass spectrometry (MS) is widely used for sequencing and identifying amino acid modifications in peptides and proteins. Identifying modifications to proteins is important for a variety of reasons. Post-translational modifications (PTMs) of proteins are necessary for a wide range of cellular functions such as protein trafficking, protein-protein interactions, and transcription. Identifying and pinpointing these modification sites are important for more deeply understanding protein function, both normal and abnormal. In this context, PTMs such as phosphorylation, acetylation, glycosylation, sulfonation, and methylation are important to characterize. Oxidation is another important protein modification that is typically associated with oxidative stress [1-4], but recent work has also shown that protein oxidation can play a regulatory role as well [5]. Furthermore, an increasing number of techniques make use of oxidative labeling to study protein structure. These methods use radicals (e.g., $\mathrm{OH})$ to modify solvent-exposed [6-9] or metal-bound

Address reprint requests to Dr. Richard W. Vachet, Department of Chemistry, Lederle GRT 701, 710 N. Pleasant St., University of Massachusetts, Amherst, MA 01003, USA. E-mail: rwvachet@chem.umass.edu

* Current address: Vertex Pharmaceuticals, Cambridge, MA.

+ Current address: Department of Developmental and Molecular Biology, Albert Einstein College of Medicine, Bronx, NY. amino acids [10-17], and $\mathrm{MS}^{\mathrm{n}}$ to identify oxidatively modified residues, typically in conjunction with proteolytic digestion.

Very often side-chain modifications to peptides can make sequencing by collision-induced dissociation (CID) difficult. Perhaps the most well known example is the effect of phosphorylation on peptide ion dissociation. The CID spectra of phosphorylated peptides are commonly dominated by a neutral loss of $\mathrm{H}_{3} \mathrm{PO}_{4}$, often with little other sequence information present. Similarly, side-chain oxidation can dramatically affect peptide dissociation patterns and limit sequence information that is available by CID. For example, oxidation of cysteine to cysteine sulfinic acid leads to selective dissociation on the C-terminal side of this residue when the peptide charge state does not exceed the number of arginine residues in the peptide [18-23]. Also, methionine oxidation to methionine sulfoxide can cause peptide CID spectra to be dominated by a neutral loss of methane sulfenic acid $\left(\mathrm{CH}_{3} \mathrm{SOH}\right)$, which can limit sequence information [24-28]. Very recently, histidine oxidation was also found to notably affect the dissociation pattern of peptides ions [29], complicating attempts to correctly sequence these peptides.

To overcome the limited sequence information that is often found in the CID spectra of modified peptides, 
alternate dissociation techniques have been used. Electron capture dissociation (ECD), implemented on a Fourier transform ion cyclotron resonance (FTICR) mass spectrometer, has been very successfully applied to sequence peptides containing labile PTMs [30-35]. Very recently, electron-transfer dissociation (ETD) on a linear ion trap was demonstrated by Hunt and coworkers [36] and subsequently by others [37, 38]. This technique is similar to ECD but uses radical anions instead of free electrons to dissociate protonated peptides. Like ECD, ETD results in c- and z-type ions that often provide abundant sequence information [36-43]. Studies indicate that ETD is particularly well suited for the characterization of peptides containing PTMs [43], but the utility of this approach for oxidized peptides has not been carefully studied.

The successful analysis of oxidized proteins, however, is very important, both broadly and in specific contexts. Some estimates indicate that about $10 \%$ of all cellular protein material in humans is oxidatively damaged, and this amount can increase 2 to 5-fold during aging $[44,45]$. Protein oxidation is also implicated in the etiology of a variety of diseases. Notable among these are neurodegenerative diseases such as Alzheimer's, which is marked by significant protein oxidation in the neuritic plaques that are the pathological hallmarks of these diseases [46, 47]. A variety of other diseases, including rheumatoid arthritis, muscular dystrophy, and cataractogenesis are also associated with elevated levels of oxidatively-damaged proteins [45]. ${ }^{\circ} \mathrm{In}^{\circ}$ this work, we report the use of ETD for sequencing oxidized cysteine- and methionine-containing peptides. Cysteine and methionine are the most readily oxidizable of the naturally occurring amino acids. Given the prevalence of protein oxidation in a variety of important contexts, analysis of peptides containing these oxidized residues is expected to be somewhat commonplace. We demonstrate that ETD provides much more reliable and abundant sequence information than CID for peptides with these oxidized residues because it overcomes the facile neutral losses typically observed in their CID spectra.

\section{Experimental}

\section{Materials}

Hydrogen peroxide (30\%), formic acid, tris(hydroxymethyl)-aminomethane (Tris), and tris(hydroxymethyl) aminomethane hydrochloride (Tris- $\mathrm{HCl}$ ) were obtained from EM Science (Gladstone, NJ). Dithiothreitol (DTT), sodium ascorbate, ascorbic acid, copper(II) sulfate, and ammonium acetate were purchased from the SigmaAldrich Corporation (St. Louis, MO). Acetic acid and HPLC-grade methanol were obtained from Fisher Scientific (Fair Lawn, NJ). Endoproteinase Asp-N was obtained from Roche Diagnostics (Indianapolis, IN), and trypsin was obtained from Promega (Madison, WI). All reagents were used as provided. Distilled, deionized water was generated with a Millipore (Burlington, MA) Simplicity 185 water purification system.

The peptides CLRRASLG, SLRRSSCFGGR, CDNQIKKM, CDPGYIGSR, CTFPGHSALMK, HCKFWW, CQDSETRTFY, RRWQWRMKKLG, YGGFMKR, and KKSRGDYMTMQIG were obtained from Sigma-Aldrich. The peptides TMVVHEKPDDLGR and TMVVHEKPDDLGRGGNEESTK are proteolytic fragments of the protein $\mathrm{Cu} / \mathrm{Zn}$ superoxide dismutase (SOD) from bovine erythrocytes, which was obtained from Sigma-Aldrich. To digest $\mathrm{Cu} / \mathrm{Zn} \mathrm{SOD}$, a $115 \mu \mathrm{L}$ solution of the protein buffered at pH 7.4 with $12 \mathrm{mM}$ ammonium acetate was mixed with $250 \mu \mathrm{M}$ DTT, and $25 \%$ (vol/vol) acetonitrile, and the mixture was incubated at $37^{\circ} \mathrm{C}$ for $30 \mathrm{~min}$. After this $30 \mathrm{~min}$ incubation, $4 \mu \mathrm{g}$ of trypsin and $0.4 \mu \mathrm{g}$ of endoproteinase Asp-N were each dissolved in $100 \mu \mathrm{L}$ of ammonium acetate (12 mM, pH 8.0) and added to the dissolved SOD mixture. This final mixture was incubated at $37^{\circ} \mathrm{C}$ for $18 \mathrm{~h}$. The reaction was terminated by changing the $\mathrm{pH}$ of the solution to $\sim 2$ by the addition of acetic acid.

\section{Peptide Oxidation}

All the peptides and proteins were oxidized using metal-catalyzed oxidation (MCO) reactions as described previously $[13,14,917] . \mathrm{MCO}^{\circ}{ }^{\circ}$ eactions ${ }^{\circ}$ with ${ }^{\circ}$ all ${ }^{\circ}$ peptides were performed at room-temperature in aqueous solutions containing $250 \mu \mathrm{M}$ peptide, $250 \mu \mathrm{M} \mathrm{CuSO}, 10$ $\mathrm{mM}$ ascorbate, $2 \mathrm{mM} \mathrm{H} \mathrm{O}_{2}$, and $50 \mathrm{mM}$ Tris- $\mathrm{HCl} /$ Tris, buffered to a $\mathrm{pH}$ of 7.4. For $\mathrm{Cu} / \mathrm{Zn} \mathrm{SOD}, \mathrm{MCO}$ reactions were performed at $37^{\circ} \mathrm{C}$ in solutions containing $40 \mu \mathrm{M}$ $\mathrm{Cu} / \mathrm{Zn}$ SOD, $100 \mathrm{mM}$ ascorbate, $2 \mathrm{mM} \mathrm{H}_{2} \mathrm{O}_{2}$, and 100 $\mathrm{mM}$ Tris/Tris- $\mathrm{HCl}$ buffered to $\mathrm{pH}$ 7.4. In all cases, the reactions were initiated by the addition of ascorbate, $\mathrm{H}_{2} \mathrm{O}_{2}$, or both. Reactions were stopped after 15 or 30 min by the addition of $1 \%$ (vol/vol) glacial acetic acid.

\section{Instrumentation}

All mass spectral measurements were carried out on a Bruker (Billerica, MA) HCTultra PTM Discovery quadrupole ion trap mass spectrometer equipped with an Agilent HPLC Chip Cube, G4240A (Santa Clara, CA). This mass spectrometer uses either CID or ETD to generate tandem mass spectra. For the CID experiments described in this work, an activation time of $40 \mathrm{~ms}$ was used. The amplitude of the resonance excitation voltage during the CID experiments was $1.0 \mathrm{~V}$, and the SmartFrag procedure was used to ensure efficient ion dissociation. The SmartFrag procedure varies the resonance excitation amplitude from $30 \%$ to $200 \%$ of its value over the course of the activation period. ETD was performed with fluoranthene radical anions that were generated via negative chemical ionization with methane reagent gas. Samples were infused at a flow rate of $0.3 \mu \mathrm{L} / \mathrm{min}$ via the Agilent G4240-61,001 MS calibration and diagnostic chip and a Cole Palmer syringe pump (Vernon Hills, IL). When performing ETD, low $\mathrm{m} / \mathrm{z}$ cutoff 
(LMCO) values ranging from 30 to 200 were used with reaction times ranging from $50 \mathrm{~ms}$ to $180 \mathrm{~ms}$. The LMCO values and reaction times were chosen to give the most efficient precursor ion dissociation. The accumulation time for the fluoranthene radical anion was 3 ms. In some cases, collisional activation was used to aid the ETD of doubly-charged ions. In the context of the ETD experiment, this collisional activation process uses a low-amplitude $(\sim 0.3 \mathrm{~V})$ resonance excitation voltage to resonantly excite any singly-charged radical cations that do not dissociate upon ETD of the doubly-charged precursor ion. This method, which is standard on the Bruker HCTultra PTM Discovery system, is similar to $a^{\circ}$ approach ${ }^{\circ}$ escribed $^{\circ}{ }^{\circ}$ ery ${ }^{\circ}$ recently $^{\circ}[42]$.

\section{Results and Discussion}

\section{Peptides with Cysteine Sulfinic Acid Residues}

Oxidation of cysteine side chains can dramatically change the CID spectra of peptides containing this amino acid. Very often the CID spectra of such peptides contain less sequence information. This effect has been observed $^{\circ}$ previously $^{\circ}\left[18^{\circ}-23\right]^{\circ}$ and $^{\circ}$ an $^{\circ}$ example ${ }^{\circ}$ of ${ }^{\circ}$ this can be seen upon comparing the CID spectra of the doubly-charged ions of CLRRASLG and C*LRRASLG, where ${ }^{\circ} \mathrm{C}^{* \circ}$ is $^{\circ}$ cysteine $^{\circ}$ sulfinic ${ }^{\circ}$ acid $^{\circ}\left(\right.$ Figure $\left.^{\circ} 1\right) .{ }^{\circ}$ The $^{\circ} \mathrm{CID}$ spectrum $\left.^{\circ}\left(\text { Figure }^{\circ} 1 \mathrm{a}\right)^{\circ}\right)^{\circ} f^{\circ}$ unoxidized $^{\circ} \mathrm{CLRRASLG}^{\circ}\left[\mathrm{M}^{\circ}+\right.$ $2 \mathrm{H}]^{2+}$, contains numerous product ions such that the sequence of this ion can be determined. In contrast, the $\mathrm{CID}^{\circ}$ spectrum $^{\circ}\left(\text { Figure }^{\circ} 1 \mathrm{~b}\right)^{\circ}$ of $^{\circ}$ the ${ }^{\circ}$ doubly-oxidized ${ }^{\circ}$ peptide $[\mathrm{M}+2 \mathrm{O}+2 \mathrm{H}]^{2+}$ shows only two abundant product ions, one at $\mathrm{m} / \mathrm{z} 414.3$ and another at $\mathrm{m} / \mathrm{z} 386.2$. With only two product ions, not enough information is present to allow this peptide to be sequenced. The product ion at $\mathrm{m} / \mathrm{z} 414.3$ arises from a unique and previously unreported dissociation pathway that results in the loss of $81 \mathrm{Da}$. The proposed mechanism for this unique dissociation pathway will be discussed below. The product ion at $\mathrm{m} / \mathrm{z} 386.2$ is the $\mathrm{y}_{7}{ }^{2+}$ product ion, and this product ion was expected based on previous work. Wang and coworkers demonstrated that the oxidation of cysteine to cysteine sulfinic acid results in facile cleavage of the peptide bond on the C-terminal side ${ }^{\circ}$ f the ${ }^{\circ}$ cysteine ${ }^{\circ}$ sulfinic ${ }^{\circ}$ acid ${ }^{2}$ residues ${ }^{\text {upon }}{ }^{\circ} \mathrm{CID}$ [22]. This dissociation pathway arises due to the acidity of cysteine sulfinic acid, which allows it to donate a proton to facilitate the cleavage of nearby peptide bonds when the number of basic residues is greater than or equal to the number of protons on the ion. The proposed mechanism for this cleavage is similar to the mechanism proposed for the cleavage of the amide bond at the C-terminal ${ }^{\circ}$ side $^{\circ}$ of ${ }^{\circ}$ aspartic ${ }^{\circ}$ acid ${ }^{\circ}$ Pesidues $^{9}$ [48]. This ${ }^{\circ}$ facile cleavage at the C-terminal side of the cysteine sulfinic acid typically leads to limited sequence information in CID spectra of cysteine sulfinic acid containing peptides.

To get more sequence information, an ETD spectrum of the doubly oxidized C*LRRASLG peptide ion
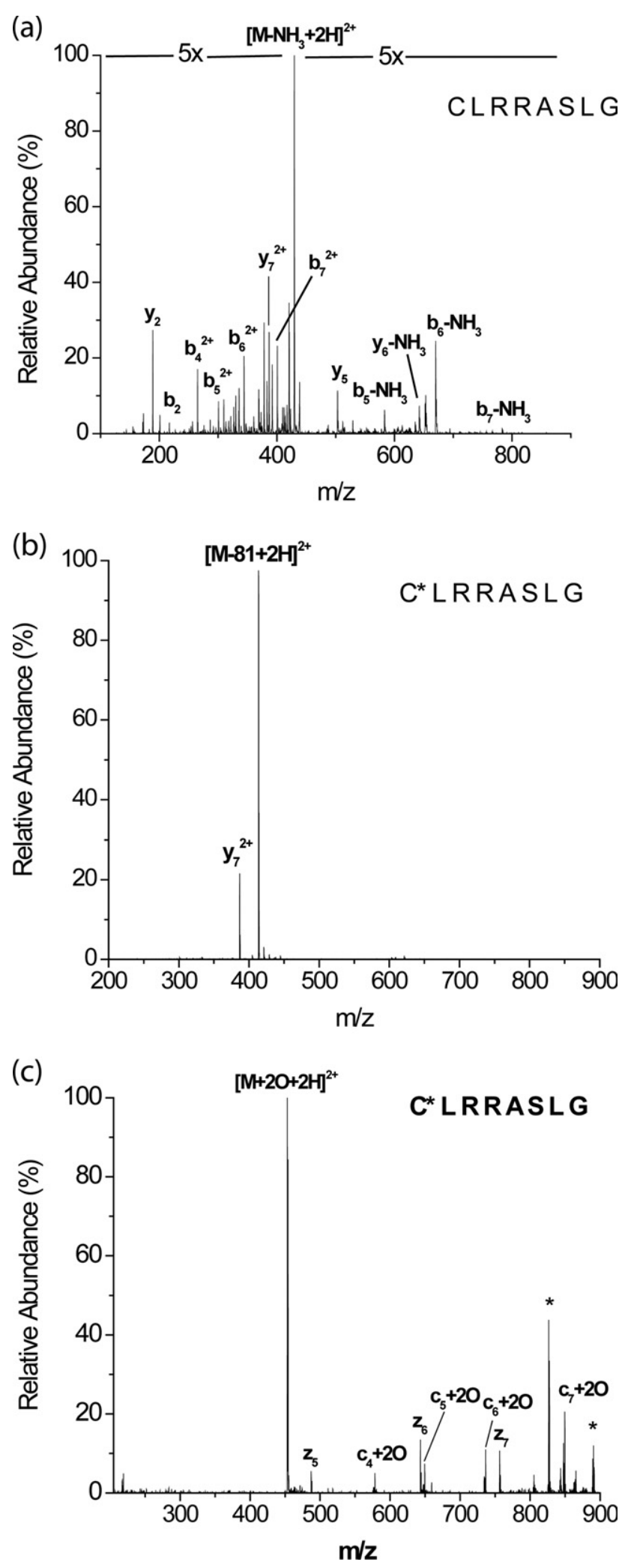

Figure 1. (a) CID of unoxidized CLRRASLG $[\mathrm{M}+2 \mathrm{H}]^{2+},(\mathbf{b}) \mathrm{CID}$ of doubly oxidized C*LRRASLG $[\mathrm{M}+2 \mathrm{O}+2 \mathrm{H}]^{2+}$, and (c) ETD of doubly oxidized C*LRRASLG $[\mathrm{M}+2 \mathrm{O}+2 \mathrm{H}]^{2+}$. The peaks labeled with an asterisk $\left(^{*}\right)$ in (c) are CID product ions. 

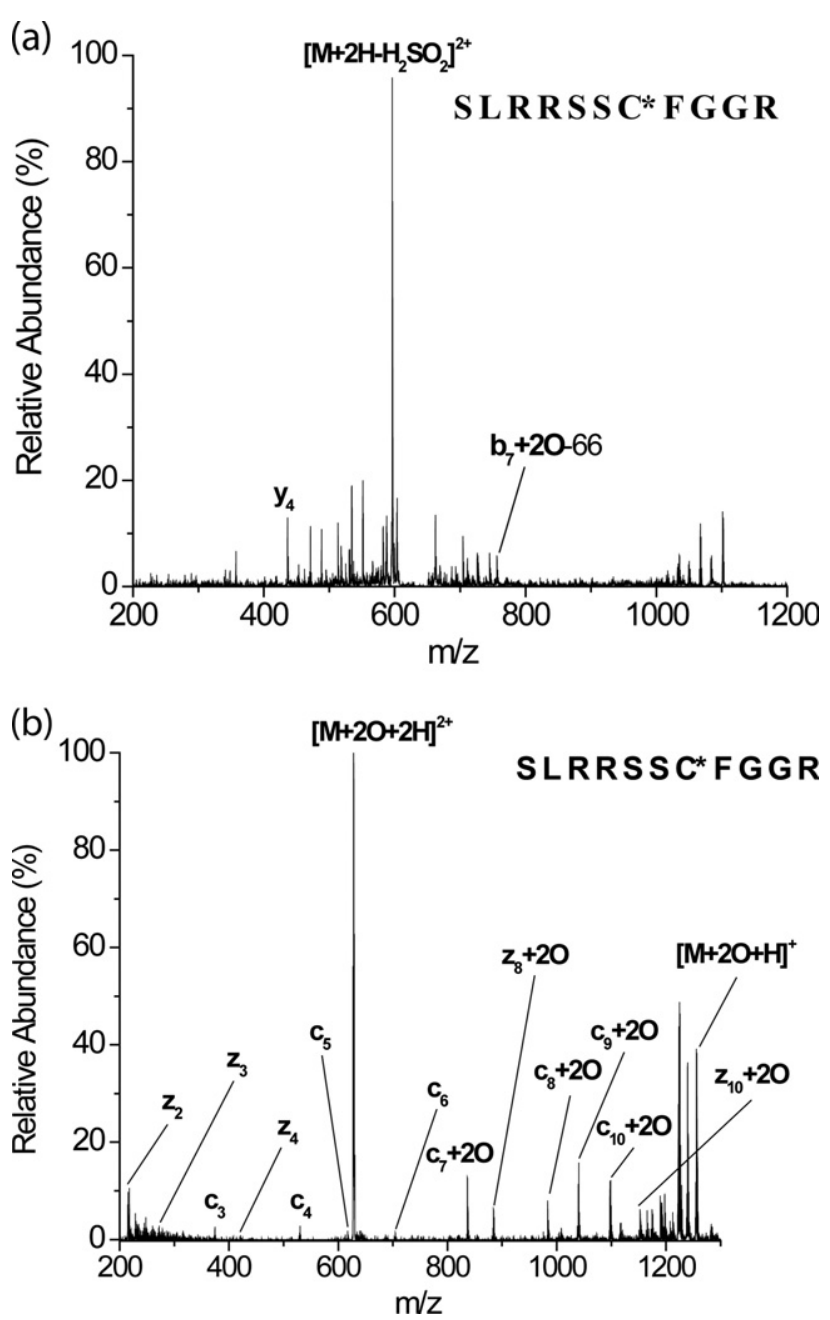

Figure 2. (a) CID of doubly oxidized SLRRSSC*FGGR [M $+2 \mathrm{O}+$ $2 \mathrm{H}]^{2+}$ and (b) ETD of doubly oxidized SLRRSSC*FGGR $[\mathrm{M}+2 \mathrm{O}+$ $2 \mathrm{H}]^{2+}$.

$\left[\mathrm{M}^{\circ}+{ }^{\circ} 2 \mathrm{O}^{\circ}+{ }^{\circ} 2 \mathrm{H}\right]^{2+^{\circ}}{ }^{\circ}$ was $^{\circ}$ obtained $^{\circ}\left(\right.$ Figure $\left.^{\circ} 1 \mathrm{c}\right) .^{\circ}$ The presence of unoxidized $\mathrm{z}_{5}, \mathrm{z}_{6}$, and $\mathrm{z}_{7}$ product ions, and oxidized $c_{4}, c_{5}, c_{6}$, and $c_{7}$ product ions allows the sequence to be determined and the site of oxidation to be identified. Clearly, oxidized cysteine does not limit the amount of sequence information obtainable from the ETD spectrum of this peptide like it does the CID spectrum.

Another example in which ETD is able to provide more sequence information than CID for a peptide containing cysteine sulfinic acid involves the peptide SLRRSSC*FGGR. The CID spectrum of the $[\mathrm{M}+2 \mathrm{O}+$ $2 \mathrm{H}]^{2+}$ ion of this peptide is dominated by a loss of $\mathrm{H}_{2} \mathrm{SO}_{2}$ (Figure ${ }^{\circ} 2 \mathrm{a}$ ). ${ }^{\circ} \mathrm{The}^{\circ} \operatorname{loss}^{\circ}$ of ${ }^{\circ} \mathrm{H}_{2} \mathrm{SO}_{2}$ from cysteine sulfinic acid containing peptides has been demonstrated by several groups to be a major dissociation pathway for peptides containing cysteine sulfinic acid residues $^{\circ}\left[22,{ }^{\circ} 49\right] . .^{\circ}$ The $^{\circ}$ spectrum ${ }^{\circ}$ also $^{\circ}$ shows ${ }^{\circ}$ modestly abundant $\mathrm{y}_{4}$ and $\left[\mathrm{b}_{7}+2 \mathrm{O}-\mathrm{H}_{2} \mathrm{SO}_{2}\right]^{+}$product ions, which arise from the enhanced cleavages that typically occur at peptide bonds adjacent to cysteine sulfinic acid.
Here again the CID spectrum provides insufficient sequence information. The $^{\circ}$ ETD $^{\circ}$ spectrum ${ }^{\circ}$ (Figure $2 \mathrm{~b}$ ) ${ }^{\circ}$ of the same precursor ion, on the other hand, is much more informative. The spectrum shows unoxidized $\mathrm{c}_{3}-\mathrm{c}_{6}$ ions, oxidized $\mathrm{c}_{7}-\mathrm{c}_{10}$ ions, unoxidized $\mathrm{z}_{2}-\mathrm{z}_{4}$ ions, and oxidized $z_{8}$ and $z_{10}$ ions, which provide almost complete sequence coverage and clearly indicate that Cys7 is oxidized. The greater sequence information present in the ETD spectra of this peptide and other peptides with cysteine sulfinic acid residues arises because of the nature of the dissociation process in ETD. While the details of the dissociation mechanism in ETD have not been fully characterized, ETD does not appear to rely on the mobilization of protons to dissociate peptides as is the case in CID. ETD has a unique propensity to randomly cleave $\mathrm{N}-\mathrm{C}_{\alpha}$ bonds of the peptide backbone with relatively little regard to peptide length, amino acid $^{\circ}{ }^{\circ}$ omposition ${ }^{\circ}$ and $^{\circ}{ }^{\circ} \mathrm{TMs}^{\circ}\left[36{ }^{\circ} .{ }^{\circ}\right.$ So, ${ }^{\circ}$ just ${ }^{\circ}$ as $^{\circ}$ ETD $^{\circ}$ provides sufficient sequence information for phosphorylated peptides in cases where CID fails, so does it provide sufficient sequence information for cysteine sulfinic acid containing peptides. The limited sequence information that results from CID of peptides with cysteine sulfinic acid is fairly common when the number of charges on a peptide ion is equal to or less than the number of basic residues in the peptide; however, the increased sequence coverage possible for these peptides when ETD is used is also likely to be quite common. We have obtained results similar to those shown ${ }^{\circ}$ in $^{\circ}$ Figures $^{\circ} 1^{\circ}$ and ${ }^{\circ} 2^{\circ}$ for ${ }^{\circ}$ several ${ }^{\circ}$ other ${ }^{\circ}$ peptides containing cysteine sulfinic acid. These peptides include CDNQIKKM, CDPGYIGSR, CTFPGHSALMK, and HCKFWW.

\section{Unique Dissociation Pattern of Peptides Having Cysteine Sulfinic Acid on the N-Terminus}

As noted above, the loss of $81 \mathrm{Da}$ from peptides with cysteine sulfinic acid on the N-terminus becomes a dominant peak in the CID spectra of peptides in which the number of basic residues equals or exceeds the peptide ${ }^{\circ}$ charge $^{\circ}$ state $^{\circ}$ (e.g., ${ }^{\circ}$ Figure $\left.^{\circ} 1 b\right) .^{\circ}{ }^{\circ}$ This ${ }^{\circ}$ dissociation pattern usually occurs instead of the loss of $\mathrm{H}_{2} \mathrm{SO}_{2}(66$ $\mathrm{Da})$, which is usually diagnostic for cysteine sulfinic acid containing peptides. This new dissociation pathway has not been reported previously for any other cysteine sulfinic acid containing peptides. To investigate the mechanism of this unique dissociation pathway, we have studied several peptides containing cysteine sulfinic acid on the $\mathrm{N}$-terminus. These peptides include CLRRASLG, CTFPGHSALMK, CQDSETRTFY, CDPGYIGSR, and CDNQIKKM. The CID spectra of these peptides show a predominant product ion that corresponds to a loss of $81 \mathrm{Da}$. Several pieces of experimental data provide insight into the likely mechanism for this neutral loss. These data include: (1) the mass of this neutral (i.e., $81 \mathrm{Da}$ ) is consistent with a loss of $\mathrm{NH}_{3}$ and $\mathrm{SO}_{2}$; (2) the loss of $81 \mathrm{Da}$ is only seen for 


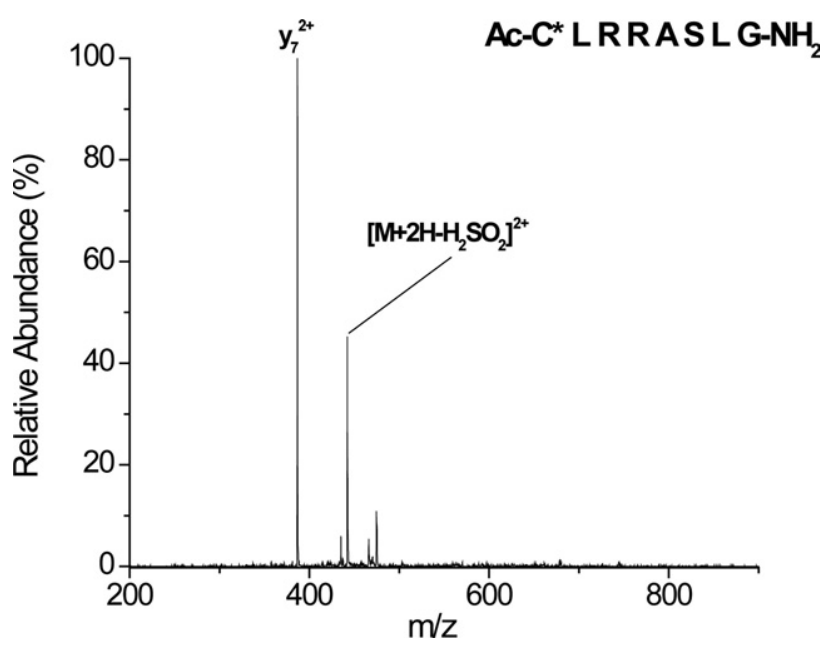

Figure 3. CID spectrum of the doubly oxidized $\mathrm{N}$-acetylated peptide C*LRRASLG $[\mathrm{N}-\mathrm{Ac}-\mathrm{M}+2 \mathrm{O}+2 \mathrm{H}]^{2+}$.

peptides that have cysteine sulfinic acid on the Nterminus; peptides with internal or C-terminal cysteine sulfinic acid residues do not form this product ion (e.g., Figure $\left.{ }^{\circ} 2 \mathrm{a}\right) ;^{\circ}(3)^{\circ}$ the ${ }^{\circ} b^{\circ}$ ions ${ }^{\circ}$ formed ${ }^{\circ}$ by $^{\circ} \mathrm{MS}^{3^{\circ}}$ of ${ }^{\circ}$ the ${ }^{\circ}$ ion corresponding to the loss of 81 Da produce $b_{n}-81$ ions, indicating this loss occurs from the N-terminus; (4) tandem mass spectra of deuterated peptides show a loss of $84 \mathrm{Da}$ instead of $81 \mathrm{Da}$, which is consistent with a loss of $\mathrm{ND}_{3}$ and $\mathrm{SO}_{2}$; (5) when the N-terminus of these peptides is acetylated, the dissociation pathway is shut down ${ }^{\circ}$ (e.g., ${ }^{\circ}$ Figure 3 ), ${ }^{\circ}$ and ${ }^{\circ}$ the ${ }^{\circ} \operatorname{loss}^{\circ}$ of $^{\circ} 81^{\circ} \mathrm{Da}{ }^{\circ}$ is ${ }^{\circ}$ replaced by a neutral loss of $66 \mathrm{Da}$ (i.e., $\mathrm{H}_{2} \mathrm{SO}_{2}$ ). These experimental data allow us to propose a mechanism for this reaction, which is shown in Scheme 1. The intramolecular interaction between sulfinic acid and the $\mathrm{N}$-terminal amine group generates a six-membered cyclic intermediate, which facilitates the neutral losses of $\mathrm{NH}_{3}$ and $\mathrm{SO}_{2}$. This mechanism is analogous to the mechanism invoked to explain the preferential cleavage of peptide bonds $^{\circ}$ adjacent $^{\circ}$ to $^{\circ}$ cysteine $^{\circ}$ sulfinic $^{\circ}$ acid $^{\circ}$ residues $^{\circ}[22]$. The mechanism is also consistent with all of our observed experimental data.

\section{Peptides with Oxidized Methionine Residues}

Like oxidized cysteine residues, oxidized methionine residues can also dramatically limit the amount of sequence information obtained from CID of peptides containing this residue. The CID spectrum of oxidized RRWQWRM*KKLG, $[\mathrm{M}+\mathrm{O}+3 \mathrm{H}]^{3+}$, where $\mathrm{M}^{*}$ is

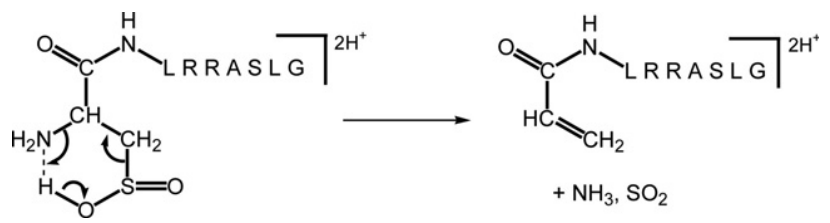

Scheme 1. Proposed dissociation mechanism for the loss of 81 Da from doubly oxidized C*LRRASLG.
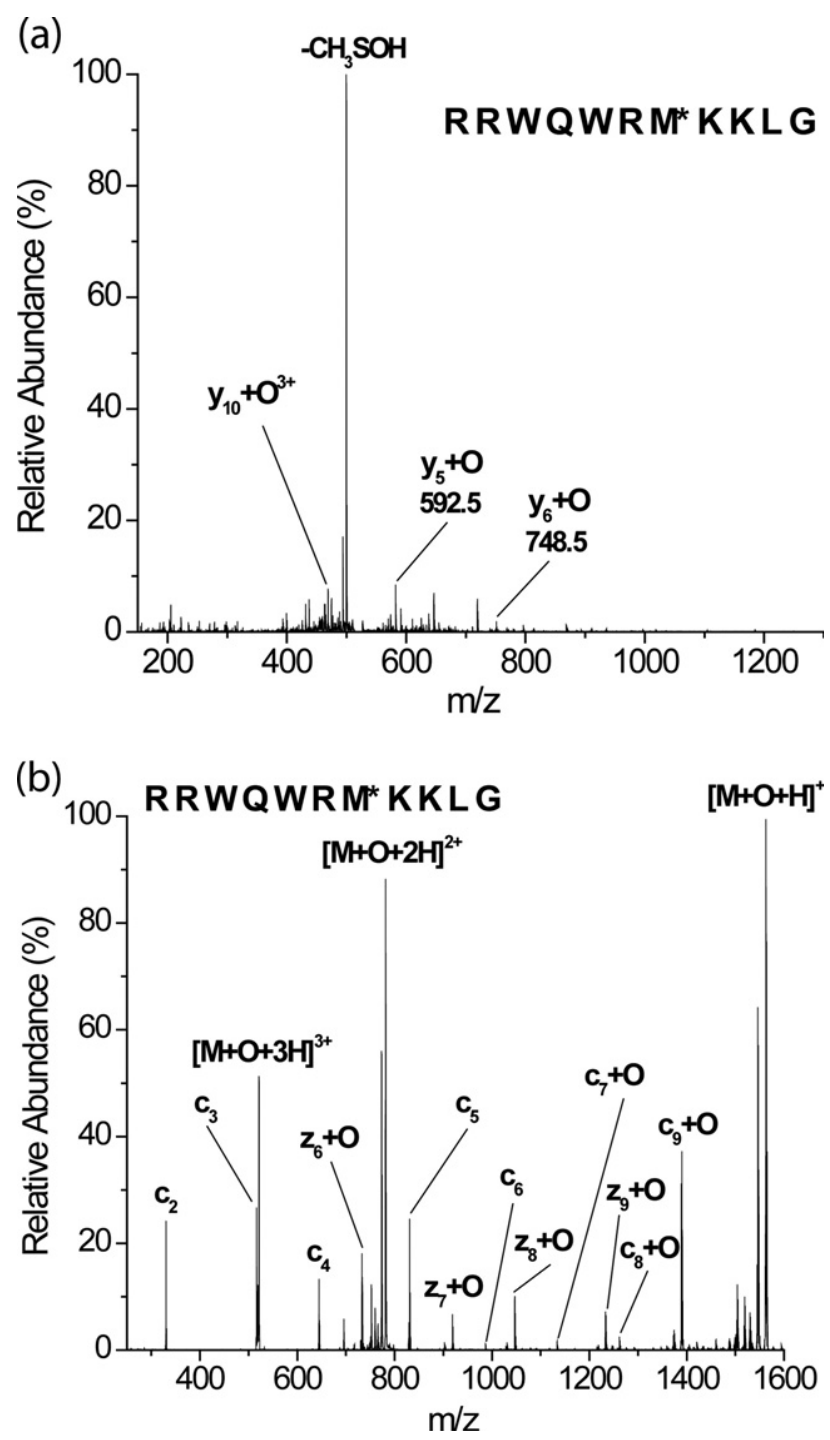

Figure 4. (a) CID of oxidized RRWQWRM*KKLG [M + O + $3 \mathrm{H}]^{3+}$ and (b) ETD of oxidized RRWQWRM*KKLG $[\mathrm{M}+\mathrm{O}+$ $3 \mathrm{H}]^{3+}$

methionine ${ }^{\circ}$ sulfoxide, ${ }^{\circ}$ illustrates ${ }^{\circ}$ this $^{\circ}$ effect $^{\circ}$ (Figure $\left.{ }^{\circ} 4 \mathrm{a}\right)$. The dominant peak in this spectrum is at $\mathrm{m} / \mathrm{z} 499.6$, which corresponds to the loss of methane sulfenic acid $\left(\mathrm{CH}_{3} \mathrm{SOH}\right)$. Jiang et al. have demonstrated that this is a diagnostic product ion from the side-chain of methionine sulfoxide ${ }^{\circ}[24] .^{\circ}{ }^{\circ}$ The ${ }^{\circ}$ spectrum ${ }^{\circ}$ also ${ }^{\circ}$ shows ${ }^{\circ}$ several $^{\circ}$ product ions of low abundance, including $\left[\mathrm{y}_{10}+\mathrm{O}\right]^{3+}, \mathrm{y}_{5}+\mathrm{O}$, and $\mathrm{y}_{6}+\mathrm{O}$. The facile loss of $\mathrm{CH}_{3} \mathrm{SOH}$ limits other dissociation pathways that might provide more sequence information. In contrast, the ETD spectrum of RRWQWRM*KKLG, $[\mathrm{M}+\mathrm{O}+3 \mathrm{H}]^{3+}$ contains unoxidized $c_{2}-c_{6}$ ions, oxidized $c_{7}-c_{9}$ ions, and oxidized $z_{6}-z_{9}$ ions, which provide almost complete sequence coverage and $^{\circ}{ }^{\circ}$ Clearly ${ }^{\circ}$ indicate that $^{\circ} \mathrm{Met}^{\circ}{ }^{\circ} \mathrm{s}^{\circ}$ oxidized $^{\circ}$ (Figure $\left.4 \mathrm{~b}\right)$.

Another example in which ETD facilitates sequencing of a peptide containing methionine sulfoxide involves ${ }^{\circ}$ the ${ }^{\circ}$ peptide ${ }^{\circ} \mathrm{KKSRGDYM}^{*} \mathrm{TM}^{*} \mathrm{QIG}^{\circ}\left(\right.$ Figure $^{\circ}$ 5). The CID spectrum of this peptide actually contains 

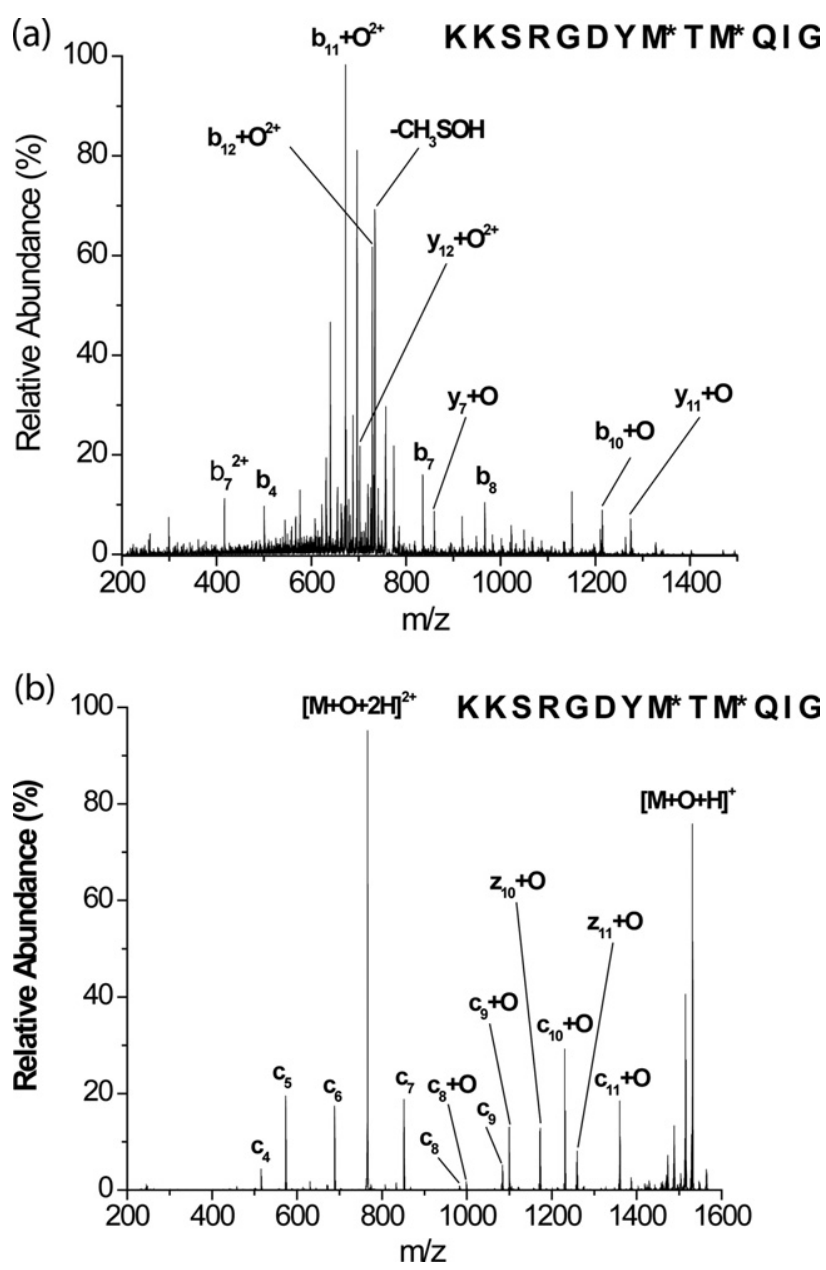

Figure 5. (a) CID of oxidized KKSRGDYM*TM*QIG $[\mathrm{M}+\mathrm{O}+$ $2 \mathrm{H}]^{2+}$ and (b) ETD of oxidized KKSRGDYM ${ }^{*} \mathrm{TM}^{*} \mathrm{QIG}[\mathrm{M}+\mathrm{O}+$ $2 \mathrm{H}]^{2+}$.

several sequence ions despite the dominant loss of $\mathrm{CH}_{3} \mathrm{SOH}$, but the spectrum does not give definitive data about the oxidation status of Met8 and Met10 (Figure $\left.{ }^{\circ} 5 \mathrm{a}\right) .{ }^{\circ}$ Indeed, ${ }^{\circ}$ the ${ }^{\circ} \mathrm{CID}{ }^{\circ}$ data ${ }^{\circ}$ seems ${ }^{\circ}$ to ${ }^{\circ}$ indicate that Met10, but not Met8, is oxidized despite the fact LC data (not shown) indicate that the dissociated peptide ion is actually a mixture of two isomers differing only by which Met residue is oxidized. Once again, the ETD spectrum gives much clearer sequence information, especially with regard to the oxidation status of Met8 and ${ }^{\circ} \mathrm{Met}^{\circ} 0^{\circ}$ (Figure ${ }^{\circ} \mathrm{bb}$ ). ${ }^{\circ}$ Indeed, ${ }^{\circ}$ the ${ }^{\circ}$ relative ${ }^{\circ}$ product ${ }^{\circ}$ ion ratios for $c_{8} / c_{8}+O$ and $c_{9} / c_{9}+O$ indicate that the Met8 isomer of this peptide comprises about $75 \%$ of the total precursor ion abundance. Thus, the ETD data provide an accurate indication of the oxidation status of both Met residues, whereas the CID data were ambiguous in this regard.

The facile loss of methane sulfenic acid, which occurs when the number of charges on a peptide ion is equal to or less than the number of basic residues in the peptide, often leads to limited sequence information in CID spectra of methionine sulfoxide-containing peptides. Because of the nature of the ETD mechanism, this neutral loss is nonexistent in the ETD spectra of these peptides, and so sequence information can be more readily obtained for these peptides. We have obtained results $^{\circ}$ similar $^{\circ}$ to ${ }^{\circ}$ those ${ }^{\circ}$ shown $^{\circ}$ in ${ }^{\circ}$ Figures $^{\circ} 4^{\circ}$ and ${ }^{\circ} 5^{\circ}$ for several other peptides containing methionine sulfoxide, including YGGFMKR, TMVVHEKPDDLGRGGNEESTK, and TMVVHEKPDDLGR.

\section{ETD Is Relatively Insensitive to Side-Chain Chemistry}

Based on observations described above, ETD provides more sequence information than CID for oxidized cysteine and methionine-containing peptides because ETD seems to be less sensitive to the side-chain chemistry of these oxidized residues. We decided to further investigate this idea by cataloging the relative ion abundances for $\mathrm{c}$ and $\mathrm{z}$ ions in the ETD spectra of all the unoxidized and oxidized peptides that we have studied. In each case, the spectra were normalized to the most abundant
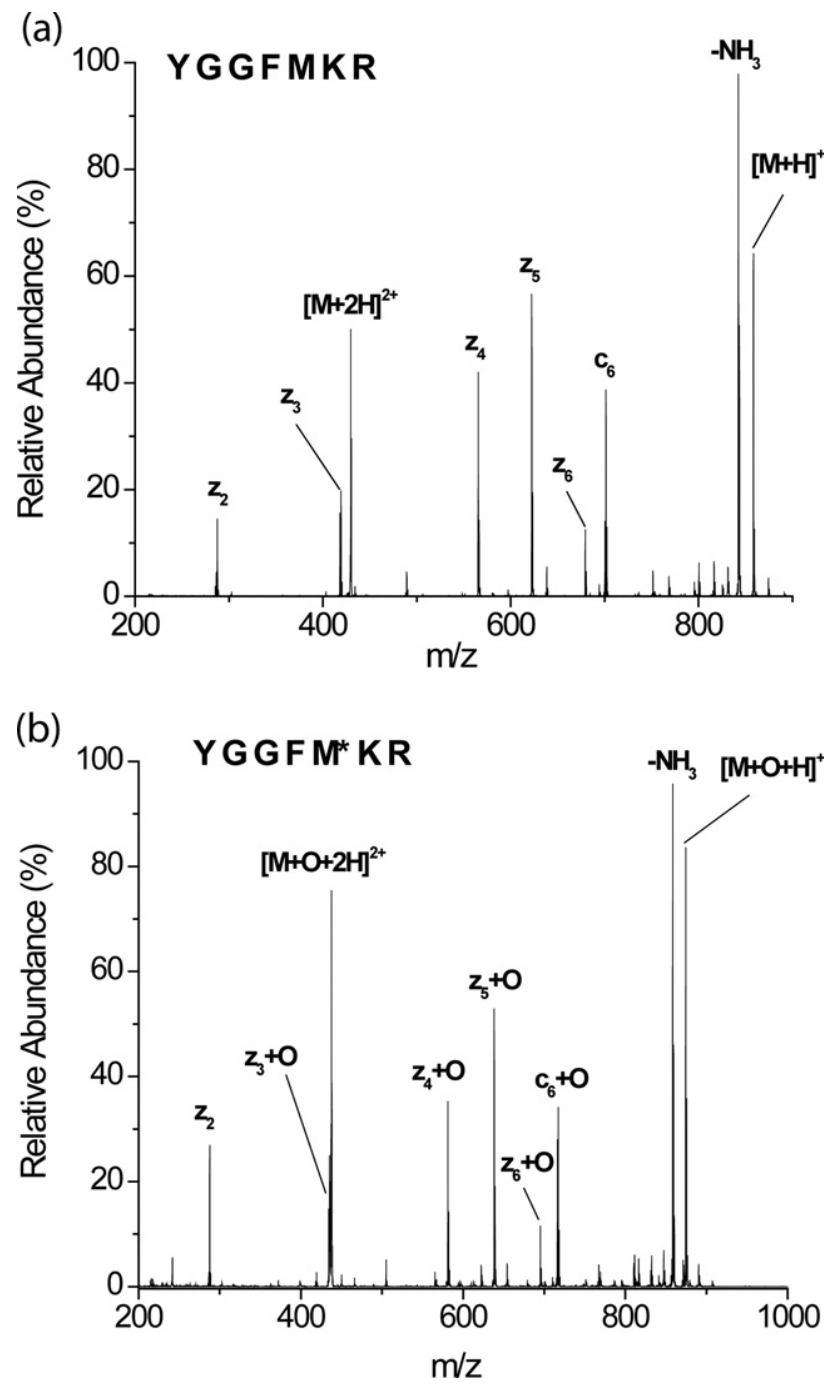

Figure 6. (a) ETD of unoxidized YGGFMKR $[\mathrm{M}+2 \mathrm{H}]^{2+}$ and (b) ETD of oxidized YGGFM*KR $[\mathrm{M}+\mathrm{O}+2 \mathrm{H}]^{2+}$. 
product ion in the spectrum. Not surprisingly, the relative abundances of most sequence ions are similar in the ETD spectra of unoxidized and oxidized peptides. As an example, the ETD spectra of the unoxidized and oxidized $^{\circ}$ form $^{\circ}$ of $^{\circ}$ YGGFMKR $^{\circ}$ are $^{\circ}$ shown $^{\circ}$ in $^{\circ}$ Figure $^{\circ} 6$. The similarities between the relative ion abundances of the observed product ions are clear. The only major differences between the two spectra are that many of the product ions in YGGFM*KR are oxidized because Met5 is oxidized. When the ETD spectra of this peptide and other cysteine- and methionine-containing peptides and their oxidized counterparts are compared, the percentage of product ions that have similar relative abundances is $65 \%$. This percentage was obtained by dividing the total number of product ions with similar relative abundances (i.e., within $10 \%$ ) by the total number of product ions observed in the spectra; this was done for all the unoxidized and oxidized peptides. As an ${ }^{\circ}$ example ${ }^{\circ}$ of ${ }^{\circ}$ this ${ }^{\circ}$ evaluation, ${ }^{\circ}$ Figure ${ }^{\circ} 6^{\circ}$ shows ${ }^{\circ}$ that ${ }^{\circ}$ the $z_{3}, z_{4}, z_{5}, z_{6}$, and $c_{6}$ product ions have relative abundances that are very similar (i.e., within $10 \%$ relative abundance) in both spectra, whereas the relative abundances of the $z_{2}$ product ion are 14 and $27 \%$, respectively, in the spectra of the unoxidized and oxidized peptides. By this analysis, the $z_{3}, z_{4}, z_{5}, z_{6}$, and $c_{6}$ product ions are established as similar in both spectra, but the $z_{2}$ product ion is considered dissimilar. For comparison, if the same analysis is done for the CID spectra of all the unoxidized and oxidized peptides, the percentage of product ions that have similar relative abundances is $3 \%$. The higher percentage of similarity in the case of the ETD spectra indicates that this technique is significantly less sensitive to the side-chain chemistry of oxidized cysteine and methionine residues than CID. So, ETD can provide more reliable sequence information and more straightforward spectral interpretations than CID for peptides containing oxidized cysteine and methionine residues.

\section{Conclusions}

The results reported here clearly show that ETD can provide more sequence information than CID for peptides with oxidized cysteine and methionine residues, particularly when the peptide's charge state is equal to or less than the number of basic residues. Peptide dissociations after ETD are much less sensitive to side-chain modifications on cysteine and methionine residues. We also report for the first time a unique dissociation pathway for peptides having $\mathrm{N}$-terminal cysteine sulfinic acid residues. The mechanism for this new dissociation pathway involves a six-membered cyclic intermediate that involves the side-chain of cysteine sulfinic acid and the N-terminal amine and leads to the facile loss of $\mathrm{NH}_{3}$ and $\mathrm{SO}_{2}$, which corresponds to a mass loss of $81 \mathrm{Da}$.

\section{Acknowledgments}

This work was supported by a grant from the National Institutes of Health (RO1 GM075092).

\section{References}

1. Davies, M. J.; Fu, S.; Wang, H.; Dean, R. T. Stable Markers of Oxidant Damage to Proteins and Their Application in the Study of Human Disease. Free Rad. Biol. Med. 1999, 27, 1151-1163.

2. Davies, M. J. The Oxidative Environment and Protein Damage. Biochim. Biophys. Acta 2005, 1703, 93-109.

3. Hawkins, C. L.; Davies, M. J. Generation and Propagation of Radical Reactions on Proteins. Biochim. Biophys. Acta. 2001, 1504, 196-219.

4. Finkel, T.; Holbrook, N. J. Oxidants, Oxidative Stress, and the Biology of Aging. Nature 2000, 408, 239-247.

5. Lee, J.-W.; Helmann, J. D. The PerR Transcription Factor Senses $\mathrm{H}_{2} \mathrm{O}_{2}$ by Metal-Catalyzed Histidine Oxidation. Nature 2006, 440, 363-367.

6. Guan, J. Q.; Chance, M. R. Structural Proteomics of Macromolecular Assemblies Using Oxidative Footprinting and Mass Spectrometry. Trends Biochem. Sci. 2005, 30, 583-592.

7. Maleknia, S. D.; Downard, K. M. Radical Approaches to Probe Protein Structure, Folding, and Interactions by Mass Spectrometry. Mass Spectrom. Rev. 2001, 20, 388-401.

8. Kiselar, J. G.; Maleknia, S. D.; Sullivan, M.; Downard, K. M.; Chance, M. R. Hydroxyl Radical Probe of Protein Surfaces Using Synchrotron X-Ray Radiolysis and Mass Spectrometry. Int. J. Radiat. Biol. 2002, 78, 101-114.

9. Takamoto, K.; Chance, M. R. Radiolytic Protein Footprinting with Mass Spectrometry to Probe the Structure of Macromolecular Complexes. Annu. Rev. Biophys. Biomol. Struct. 2006, 35, 251-276.

10. Kurahashi, T.; Miyazaki, A.; Suwan, S.; Isobe, M. Extensive Investigations on Oxidized Amino Acid Residues in $\mathrm{H}_{2} \mathrm{O}_{2}$-Treated $\mathrm{Cu} / \mathrm{Zn}$-SOD Protein with LC-ESI-Q-TOF-MS, MS/MS for the Determination of the Copper-Binding Site. J. Am. Chem. Soc. 2001, 123, 9268-9278.

11. Hovorka, S. W.; Williams, T. D.; Schöneich, C. Characterization of the Metal-Binding Site of Bovine Growth Hormone Through Site-Specific Metal Catalyzed Oxidation and High-Performance Liquid Chromatography-Tandem Mass Spectrometry. Anal. Biochem. 2002, 300, 206-211.

12. Schöneich, C.; Williams, T. D. Cu(II)-Catalyzed Oxidation of $\beta$-Amyloid Peptide Targets His13 and His14 over His6: Detection of 2-Oxo-histidine by HPLC-MS/MS. Chem. Res. Toxicol. 2002, 15, $717-722$.

13. Lim, J.; Vachet, R. W. Development of a Methodology Based on Metal-Catalyzed Oxidation Reactions and Mass Spectrometry to Determine the Metal Binding Sites in Copper Metalloproteins. Anal. Chem. 2003, 75, 1164-1172.

14. Lim, J.; Vachet, R. W. Using Mass Spectrometry to Study CopperProtein Binding Under Native and Non-Native Conditions: $\beta-2-$ Microglobulin. Anal. Chem. 2004, 76, 3498-3504.

15. Bridgewater, J. D.; Vachet, R. W. Metal-Catalyzed Oxidation Reactions and Mass Spectrometry: The Roles of Ascorbate and Different Oxidizing Agents in Determining Cu-Protein-Binding Sites. Anal. Biochem. 2005, $41,122-130$.

16. Bridgewater, J. D.; Vachet, R. W. Using Microwave-Assisted MetalCatalyzed Oxidation Reactions and Mass Spectrometry to Increase the Rate at which the Copper-Binding Sites of a Protein are Determined. Anal. Chem. 2005, 77, 4649-4653.

17. Bridgewater, J. D.; Lim, J.; Vachet, R. W. Transition Metal-Peptide Binding Studied by Metal-Catalyzed Oxidation Reactions and Mass Spectrometry. Anal. Chem. 2006, 78, 2432-2438.

18. Burlet, O.; Yang, C.-Y.; Gaskell, S. J. Influence of Cysteine to Cysteic Acid Oxidation on the Collision-Activated Decomposition of Protonated Peptides: Evidence for Intra-Ionic Interactions. J. Am. Soc. Mass Spectrom. 1992, 3, 337-344.

19. Cox, K. A.; Gaskell, S. J.; Morris, M. Whiting, A. Role of the Site of Protonation in the Low-Energy Decompositions of Gas-Phase Peptide Ions. J. Am. Soc. Mass Spectrom. 1996, 7, 522-531.

20. Summerfield, S. G.; Cox, K. A.; Gaskell, S. J. The Promotion of $d$-Type Ions During the Low Energy Collision-Induced Dissociation of Some Cysteic Acid-Containing Peptides. J. Am. Soc. Mass Spectrom. 1997, 8, 25-31.

21. Tsaprailis, G.; Nair, H.; Somogyi, A.; Wysocki, V. H.; Zhong, W.; Futrell, J. H.; Summerfield, S. G.; Gaskell, S. J. Influence of Secondary Structure on the Fragmentation of Protonated Peptides. J. Am. Chem. Soc. 1999, $121,5142-5154$

22. Wang, Y.; Vivekananda, S.; Men, L.; Zhang, Q. Fragmentation of Protonated Ions of Peptides Containing Cysteine, Cysteine Sulfinic Acid, and Cysteine Sulfonic Acid. J. Am. Soc. Mass Spectrom. 2004, 15, 697-702.

23. Men, L.; Wang, Y. Further Studies on the Fragmentation of Protonated Ions of Peptides Containing Aspartic Acid, Glutamic Acid, Cysteine Sulfinic Acid, and Cysteine Sulfonic Acid. Rapid Commun. Mass Spectrom. 2005, 19, 23-30. 
24. Jiang, X.; Smith, J. B.; Abraham, E. C. Identification of a MS-MS Fragment Diagnostic for Methionine Sulfoxide. J. Mass Spectrom. 1996, 31, 1309-1310.

25. Lagerwerf, F. M.; van de Weert, M.; Heerma, W.; Haverkamp, J. Identification of Oxidized Methionine in Peptides. Rapid Commun. Mass Spectrom. 1996, 10, 1905-1910.

26. Qin, J.; Chait, B. T. Identification and Characterization of Posttranslational Modifications of Proteins by MALDI Ion Trap Mass Spectrometry. Anal. Chem. 1997, 69, 4002-4009.

27. O'Hair, R. A. J.; Reid, G. E. Neighboring Group versus cis-Elimination Mechanisms for Side Chain Loss from Protonated Methionine, Methionine Sulfoxide and their Peptides. Eur. Mass Spectrom. 1999, 5, 325-334.

28. Reid, G. E.; Roberts, K. D.; Kapp, E. A.; Simpson, R. J. Statistical and Mechanistic Approaches to Understanding the Gas-Phase Fragmentation Behavior of Methionine Sulfoxide Containing Peptides. J. Proteome Res. 2004, 3, 751-759.

29. Bridgewater, J. D.; Srikanth, R.; Lim, J.; Vachet, R. W. The Effect of Histidine Oxidation on the Dissociation Patterns of Peptide Ions. J. Am. Soc. Mass Spectrom. 2007, 18, 553-562.

30. Zubarev, R. A.; Kelleher, N.; McLafferty, F. W. Electron Capture Dissociation of Multiply Charged Protein Cations. A Nonergodic Process. J. Am. Chem. Soc. 1998, 120, 3265-3266.

31. Stensballe, A.; Jensen, O. N.; Olsen, J. V.; Haselmann, K. F.; Zubarev, R. A. Electron Capture Dissociation of Singly and Multiply Phosphorylated Peptides. Rapid Commun. Mass Spectrom. 2000, 14, 1793-1800.

32. Bakhtiar, R.; Guan, Z. Electron Capture Dissociation Mass Spectrometry in Characterization of Post-Translational Modifications. Biochem. Biophys. Res. Commun. 2005, 334, 1-8.

33. Mirgorodskaya, E.; Roepstorff, P.; Zubarev, R. A. Localization of O-Glycosylation sites in Peptides by Electron Capture Dissociation in a Fourier Transform Mass Spectrometer. Anal. Chem. 1999, 71, 4431-4436.

34. Hakansson, K.; Chalmers, M. J. Quinn, J. P.; McFarland, M. A. Hendrickson, C. L.; Marshall, A. G. Combined Electron Capture and Infrared Multiphoton Dissociation for Multistage MS/MS in a Fourier Transform Ion Cyclotron Resonance Mass Spectrometer. Anal. Chem. 2003, 75, 3256-3262.

35. Bakhtiar, R.; Guan, Z. Electron Capture Dissociation Mass Spectrometry in Characterization of Peptides and Proteins. Biotechnol. Lett. 2006, 28, 1047-1060.

36. Syka, J. E. P.; Coon, J. J.; Schroeder, M. J.; Shabanowitz, J.; Hunt, D. F. Peptide and Protein Sequence Analysis by Electron Transfer Dissociation Mass Spectrometry. Proc. Natl. Acad. Sci. U.S.A. 2004, 101, 95289533.
37. Gunawardena, H. P.; Emory, J. F.; McLuckey, S. A. Phosphopeptide Anion Characterization via Sequential Charge Inversion and ElectronTransfer Dissociation. Anal. Chem. 2006, 78, 3788-3793.

38. Zhang, Q.; Frolov, A.; Tang, N.; Hoffmann, R.; Goor, T. V. D.; Metz, T. O.; Smith, R. D. Application of Electron Transfer Dissociation Mass Spectrometry in Analysis of Non-Enzymatically Glycated Peptides. Rapid Commun. Mass Spectrom. 2007, 21, 661-666.

39. Coon, J. J.; Syka, J. E. P.; Schwartz, J. C.; Shabanowitz, J.; Hunt, D. F. Anion Dependence in the Partitioning between Proton and Electron Transfer in Ion/Ion Reactions. Int. J. Mass Spectrom. 2004, 236, 33-42.

40. Coon, J. J.; Ueberheide, B.; Syka, J. E. P.; Dryhurst, D. D.; Ausio, J. Shabanowitz, J.; Hunt, D. F. Protein Identification using Sequential Ion/Ion Reactions and Tandem Mass Spectrometry. Proc. Natl. Acad. Sci. U.S.A. 2005, 102, 9463-9468.

41. Hogan, J. M.; Pitteri, S. J.; Chrisman, P. A.; McLuckey, S. A. Complementary Structural Information from a Tryptic N-Linked Glycopeptide Via Electron Transfer Ion/Ion Reactions and Collision-Induced Dissociation. J. Proteome Res. 2005, 4, 628-632.

42. Swaney, D. L.; McAlister, G. C.; Wirtala, M.; Schwartz, J. C.; Syka, J. E. P.; Coon, J. J. Supplemental Activation Method for High-Efficiency Electron-Transfer Dissociation of Doubly Protonated Peptide Precursors. Anal. Chem. 2007, 79, 477-485.

43. Mikesh, L. M.; Ueberheide, B.; Chi, A.; Coon, J. J.; Syka, J. E. P.; Shabanowitz, J.; Hunt, D. F. The Utility of ETD Mass Spectrometry in Proteomic Analysis. Biochim. Biophys. Acta. 2006, 1764, 1811-1822.

44. Stadtman, E. R. Protein Oxidation and Aging. Science 1992, 257, 1220 1224.

45. Berlett, B. S.; Stadtman, E. R. Reactive Oxygen-Mediated Protein Oxidation in Aging and Sisease. Chem. Res. Toxic. 1997, 10, 485-494.

46. Castegna, A.; Aksenov, M.; Aksenova, M.; Thongboonkerd, V.; Klein, J. B.; Pierce, W. M.; Booze, R.; Markesbery, W. R.; Butterfield, A. D. Proteomic Identification of Oxidatively Modified Proteins in Alzheimer's Disease Brain. Part 1. Creatine Kinase BB, Glutamine Synthetase, and Ubiquitin Carboxy-Terminal Hydrolase L-1. Free Rad. Biol. Med. 2002, 33, 562-571.

47. Mattson, M. P. Pathways Towards and Away from Alzheimer's Disease. Nature 2004, 430, 631-639.

48. Yu, W.; Vath, J. E.; Huberty, M. C.; Martin, S. A. Identification of the Facile Gas-Phase Cleavage of the Asp-Pro and Asp-Xxx Peptide Bonds in Matrix-Assisted Laser Desorption Time-of-Flight Mass Spectrometry. Anal. Chem. 1993, 65, 3015-3023.

49. Maleknia, S. D.; Brenowitz, M.; Chance, M. R. Millisecond Radiolytic Modification of Peptides by Synchrotron X-Rays Identified by Mass Spectrometry. Anal. Chem. 1999, 71, 3965-3973. 